\title{
Урожайність та фізичні властивості буряка столового за різних строків сівби
}

\author{
Л.М. Пузік ${ }^{1}$, В.А. Бондаренко ${ }^{2}$ \\ Харківський національний технічний університет сільського господарства \\ імені Петра Василенка (м.Харків, Україна) \\ email:1 ludapusik@gmail.com; ${ }^{2}$ zim-hot@rambler.ru
}

\begin{abstract}
Представлено результати досліду з вивчення впливу різних строків сівби на урожайність буряка столового та їхній вплив на фрормування фрізичних властивостей коренеплодів.

Дослідження проводили з гібридами іноземної селекції Боро $F_{1}$, Манзу $F_{1}$ та Бетті $F_{1}$. Насіння буряка столового висівали у два строки: друга декада квітня і третя декада травня. Встановлено, що строк сівби впливає на швидкість проростання насіння і появу сходів буряка столового: за сівби у третю декаду травня сходи з'являлися на 12 діб раніше, ніж за сівби у другу декаду квітня. Тривалість вегетаційного періоду буряка залежить від температури ґрунту. Оскільки оптимальною температурою для росту і розвитку коренеплодів $€ 20 \ldots 25^{\circ} \mathrm{C}$, то вище або нижче за неї ростові процеси сповільнюються, тим самим подовжується вегетаційний період до настання технічної стиглості.

Вищу врожайність коренеплодів буряк столовий формував за сівби у другу декаду квітня. Товарна врожайність і товарність продукції на 71 та 61 \% відповідно залежали від особливостей гібрида. Вищий рівень товарної урожайності був у Манзу $F_{1}$ і за сівби у другу декаду квітня становив 70,8 т/га, за сівби у третю декаду травня товарна врожайність була 65,6 т/га. Товарність продукції у Манзу $F_{1}$ за першого і другого строків сівби зберігалася на рівні $92 \%$. Проте у гібрида Бетті $F_{1}$ товарність була на рівні 93-94 \% за самої меншої серед досліджуваних гібридів урожайності: 55,9-59,7 т/га.

Такі фрізичні показники буряка столового як маса та об'єм коренеплодів залежали від особливостей гібрида відповідно на 85 та 84 \%. Вплив строку сівби становив від 7 до 12 \%. Істотно вище фізичні показники коренеплодів були за сівби у другу декаду квітня. Коренеплоди істотно більші за масою та об’ємом фрормував Манзу $F_{1}-307,8-316,5$ г та 296,7-305,5 м³ відповідно.
\end{abstract}

Ключові слова: буряк столовий, гібрид, урожайність, товарність, коренеплід, маса, об'єм, строк сівби.

У структурі харчування сучасної людини свіжі овочі займають чверть харчового раціону. Сприятливі природно-кліматичні умови для іi виробництва в Україні дають можливість задовольняти потреби вітчизняних споживачів практично у повному обсязі за рахунок власних ресурсів. Україна входить у першу десятку світових лідерів за валовим виробництвом овочевої продукції, а з розрахунку на душу населення займає шосте місце у світі. Проте, серед 20-ти передових країн світу Україна посідає 18-те місце за рівнем урожайності. Урожайність овочевих культур по території України дуже мінлива і її величина визначається забезпеченістю території світлом, теплом, вологою, продуктами живлення, а також родючістю ґрунтів та біологічними особливостями. Одним із шляхів збільшення виробництва овочевої продукції $€$ не розширення посівних площ, а підвищення її врожайності [1-3].

Буряк столовий (Beta vulgaris L. ssp. vulgaris var. conditiva Alef.) $€$ однією з найбільш розповсюджених овочевих культур в Україні. У Лісостеповій зоні він у структурі посівних площ займає близько третини і входить до складу так званого «борщового набору». Окрім гарних смакових властивостей він має і лікувально-профрілактичне значення [4-6]. Різноманіття сортів і гібридів столового буряка за скоростиглістю дозволяє забезпечити ним населення упродовж року. Проте серед вчених не існує єдиної думки щодо строків сівби цієї культури. Деякі вважають, що сіяти буряк необхідно рано навесні [7], інші рекомендують сівбу у пізні весняні строки, мотивуючи це тим, що при ранніх строках спостерігається переростання коренеплодів та знижується їх лежкість [8]. Отже, питання добору строку посіву для реалізації потенційної врожайності сорта або гібрида та отримання високоякісної продукції залишається актуальним.

Основною метою роботи є вивчення впливу різних строків сівби на урожайність та фізичні властивості коренеплодів середньостиглих гібридів буряка столового. В роботі проведена порівняльна оцінка врожайності буряка столового середньостиглого залежно від строку висіву, а також встановлена залежність формування товарного врожаю від погодних умов вегетаційного періоду.

Рослини буряка столового більш вимогливі до тепла, ніж інші коренеплідні. Насіння проростає за температури $6 \ldots 8^{\circ} \mathrm{C}$, оптимальна тем- 
пература для проростання $15 \ldots 25^{\circ} \mathrm{C}$. Прогрівання грунту навесні впливає на на строки сівби та інтенсивність проростання насіння. За температури грунту $4^{\circ} \mathrm{C}$ сходи з'являються через 20-22 днів, за $10 \ldots 11^{\circ} \mathrm{C}$ - через $10-12$ днів, за $15 \ldots 18^{\circ} \mathrm{C}$ - через 4-5 діб за необхідного забезпечення вологою. Максимальні прирости маси коренеплода спостерігаються за температури вдень $21 \ldots 22^{\circ} \mathrm{C}$, вночі $17 \ldots 19^{\circ} \mathrm{C}$ і достатній вологості повітря та грунту. Під час зниження температури до $8 . .11^{\circ} \mathrm{C}$ ріст листків припиняється, а маса коренеплода збільшується завдяки відтоку асимілятів з листків. Дорослі рослини буряка витримують заморозки до $-2 . . .4^{\circ} \mathrm{C}[9]$.

Дослідження проведені у 2020 р. у селянському (фермерському) господарстві «Ковальчуківське».

Господарство розташовано в Краснокутському районі Харківської області. Ґрунт дослідної ділянки темно-сірий опідзолений на лесових породах і характеризується такими агрохімічними показниками: $\mathrm{pH}$ сольової витяжки - 5,7; загальний вміст гумусу в орному шарі 3,8 \%; N - 11,0 мг/100 г ґрунту (за Корнфільдом); $\mathrm{P}_{2} \mathrm{O}_{5}-8,8$ (за Чіріковим) та $\mathrm{K}_{2} \mathrm{O}-8,0$ мг/100 г ґрунту (за Чіріковим). Клімат Краснокутська помірно континентальний.

У 2020 році буряк столовий висівали з другої декади квітня, а збирали в кінці третьої декади вересня. Опади за цей період випадали нерівномірно. Друга декада квітня характеризувалася посушливими умовами: опадів випало - 3,0 мм, що менше в 4,5 рази від середньобагаторічного показника, а середньодобова температура була майже на рівні з багаторічним показником: $8,6^{\circ} \mathrm{C}$ До кінця травня температура повітря поступово підвищувалася до $15 \ldots 16^{\circ} \mathrm{C}$, кількість опадів збільшилася до 13,5 мм за декаду. Найбільша кількість опадів - 104 мм - випала у третій декаді травня, що було в чотири раза більше від багаторічного показника.

Червень характеризувався самою спекотною погодою: середньодобова температура збільшилася від 20 до $27^{\circ} \mathrm{C}$ в середньому за декаду. При цьому в першу декаду випало 20,0 мм опадів, у другу - 2,5 і в третій - 8,0 мм. Це обумовило гідротермічний коефіцієнт Селянинова I декади червня на рівні 1, другої - 0,1 і третьої - 0,3.

В липні середньодобова температура коливалася в межах $24 \ldots 25^{\circ} \mathrm{C}$. В першій і третій декадах місяця опадів не було. 55,0 мм випало лише у другій декаді липня.

Серпень і вересень характеризувалися відсутністю опадів. Лише в кінці вересня випало 2,0 мм опадів. Температура повітря підвищувалася 3 першої декади серпня до першої декади вересня включно від 23 до $25^{\circ} \mathrm{C}$ і була вище за середньобагаторічні показники на 2-8 C. При цьому слід відмітити, що згідно багаторічних спостережень температура від серпня до кінця вересня має знижуватися від 22 до $12^{\circ} \mathrm{C}$. У другій та третій декадах вересня середньодобова температура знаходилася на рівні $19 \ldots 20^{\circ} \mathrm{C}$.

Відносна вологість повітря за період з II-ї декади квітня по III-ю декаду вересня коливалася від 45 до 74 \% відповідно до кількості опадів і температури повітря. Отже, найбільш сприятливими умовами для росту і розвитку коренеплодів буряка столового характеризувалися погодні умови з II-ї декади квітня по I-у декаду червня включно, а також з II-ї декади липня до кінця вересня.

Дослідження проводили з середньостиглими гібридами буряка столового Боро $F_{1}$, Манзу $F_{1}$ та Бетті $F_{1}$, що внесені до Державного Реєстру сортів рослин, придатних для поширення в Україні і районовані для всіх кліматичних зон України [10]. Попередник - цибуля ріпчаста. Насіння буряка столового висівали у два строки: II декада квітня та III декада травня. Насіння висівали сівалкою точного висіву. Схема розміщення рослин $(45+20)$ x 10 см (333,3 тис. шт./га). Площа облікової ділянки в досліді $20 \mathrm{~m}^{2}$, повторність досліду чотириразова. Розміщення варіантів систематичне. Вологість ґрунту за допомогою краплинного зрошення підтримувалася на рівні 75 \% НB у шарі ґрунту 0-50 см, норма одного вегетаційного поливу - 150-200 м³/га.

Коренеплоди збирали суцільним способом. Продукцію зважували, розподіляли на товарну і нетоварну частини. Товарну частину розподіляли на стандартну і нестандартну продукцію згідно чинного державного стандарту [11]. Польовий дослід - двофакторний (фактор А - строк сівби, фактор В - особливості гібрида).

Згідно даних літературних джерел було обрано два строки висіву: I - за температури, що є мінімальною для проростання насіння: $6 . .8^{\circ} \mathrm{C}$; II - за температури, що є оптимальною для проростання насіння буряка столового. У 2020 р. І строк сівби припав на 13 квітня, а другий - на 25 травня.

Згідно наших фенологічних спостережень масові сходи дослідних гібридів з'явилися майже одночасно: через 15-16 діб за першого строку сівби, за другого - через чотири. Тобто дані науковців, що були наведені в огляді літератури повністю підтверджені.

Оскільки для досліджень використовувалися гібриди однієї групи стиглості, то тривалість вегетаційного періоду - від появи масових сходів до технічної стиглості - в них була майже однаковою. За першого строку сівби коренеплоди збирали через 125-127 діб (на початку вересня), за другого - через 122 доби (в кінці вересня). Тривалість міжфазних періодів визначалася температурою повітря: за більш високої температури вегетаційний період був менш тривалий. При цьому, за першого строку сівби на 1-2 доби швидше фази розвитку проходив гібрид Бетті $F_{1}$. 
У наших дослідженнях загальна врожайність (включає товарну і нетоварну продукцію) коренеплодів буряка столового (табл. 1) за сівби у другій декаді квітня була в межах 63,6-76,7 т/га, за сівби у третій декаді травня - 59,9-71,3 т/га. Більшою вона була у гібрида Манзу $F_{1}$, а меншою у Бетті $F_{1}$. Гібриди істотно різнилися $\left(\mathrm{HIP}_{05}=0,5\right.$ т/га) між собою за цим показником. Також істотна різниця була в межах гібрида за строками сівби. Слід відмітити, що врожайність, отримана за другого строку сівби, була менше від врожайності першого на $5,4 \%$ у Боро $F_{1}$, на $7,0 \%$ у Манзу $F_{1}$ та на $5,8 \%$ у Бетті $F_{1}$. Подібні результати були отримані I.І. Паламарчук в її дослідженнях із сортами буряка столового Бордо харківський та Опольський [12]. Дисперсійним аналізом встановлено, що загальна врожайність буряка столового на 84 \% залежить від особливостей гібрида, вплив строку сівби становить лише $14 \%$.

Таблиця 1. Урожайність буряка столового за різних строків сівби, т/га (2020р.)

\begin{tabular}{|c|c|c|c|c|}
\hline \multirow{2}{*}{$\begin{array}{c}\text { Строк сі- } \\
\text { вби }\end{array}$} & \multicolumn{3}{|c|}{ Урожайність, т/га } & \multirow{2}{*}{$\begin{array}{l}\text { Товар- } \\
\text { ність, \% }\end{array}$} \\
\hline & $\begin{array}{l}\text { това- } \\
\text { рна }\end{array}$ & $\begin{array}{l}\text { нето- } \\
\text { варна }\end{array}$ & $\begin{array}{l}\text { зага- } \\
\text { льна }\end{array}$ & \\
\hline \multicolumn{5}{|c|}{ Боро $F_{1}$} \\
\hline $\begin{array}{l}1.13 .04- \\
\text { контроль }\end{array}$ & 64,9 & 7,8 & 72,8 & 89 \\
\hline 2.25 .05 & 60,1 & 8,8 & 68,9 & 87 \\
\hline \multicolumn{5}{|c|}{ Манзу $F_{1}$} \\
\hline $\begin{array}{l}1.13 .04- \\
\text { контроль }\end{array}$ & 70,8 & 5,9 & 76,7 & 92 \\
\hline 2.25 .05 & 65,6 & 5,7 & 71,3 & 92 \\
\hline \multicolumn{5}{|c|}{ Бетті $F_{1}$} \\
\hline $\begin{array}{l}1.13 .04- \\
\text { контроль }\end{array}$ & 59,7 & 4,0 & 63,6 & 94 \\
\hline 2. 25.05 & 55,9 & 4,0 & 59,9 & 93 \\
\hline $\mathrm{HIP}_{05}$ & 1,7 & 1,3 & 0,5 & 2 \\
\hline
\end{tabular}

Товарна врожайність коренеплодів першого строку сівби була більше, ніж за другого. Різниця між гібридами за рівнем товарної урожайності і між строками сівби за цим показником була істотною $\left(\mathrm{HIP}_{05}=1,7\right.$ т/га). Манзу $F_{1}$ мав найвищу товарну врожайність серед дослідних гібридів як за першого, так і за другого строків сівби: 70,8 та 65,6 т/га відповідно. Найменша товарна врожайність була у Бетті $F_{1}$.

Дисперсійним аналізом встановлено, що вплив особливостей гібрида (фактор В) мав $71 \%$ впливу на рівень товарної врожайності, строк сівби (фактор A) - $20 \%$, сумісна дія фракторів АВ знову мала $1 \%$ впливу як і за формування загальної врожайності. Проте дія інших фракторів (ґрунтові шкідники, особливості онтогенезу тощо) збільшилася до 8 \%.

Під час аналізу впливу фракторів на фрормування нетоварної продукції буряка столового встановлено, що вплив строку сівби та сумісної дії факторів АВ становили по 1 \%. Вплив особливостей гібрида (фактор В) залишався високим $69 \%$, проте порівняно із впливом на формування загальної та товарної врожайності зменшився відповідно на 16 та $2 \%$. Вплив інших факторів зріс до 29\%.

За високої загальної врожайності продукція може мати низьку товарність і навпаки. Це може свідчити про стійкість гібрида до несприятливих умов середовища. В наших дослідженнях таким гібридом виявився Бетті $F_{1}$.

Товарна якість коренеплоду (розмір, наявність ушкоджень, характер поверхні тощо) формується під час активного його формування. Це відбувається приблизно через 20-30 днів після появи сходів і триває близько 60 днів. Тривалість цих періодів залежить від погодних умов.

За даними літературних джерел, кращі результати виходу товарних коренеплодів буряка столового одержують від висіву насіння з другої половини травня до середини червня із нормою висіву до 650 тис насінин на гектар (одноросткові сорти та гібриди) $[13,14]$.

Проте у наших дослідженнях більш сприятливі умови для формування якісних коренеплодів склалися за сівби у другу декаду квітня, що і відобразилося на більшому товарних коренеплодів 3 1 га: товарність врожаю була в межах 89-94\%. За сівби у третю декаду травня товарність коренеплодів була на 1-2 \% нижчою. Слід відмітити, що у 2020 році сума температур в період активного формування коренеплодів за сівби у другу декаду квітня становила $1450,5^{\circ} \mathrm{C}$, а за сівби у третю декаду травня $-1465,5^{\circ} \mathrm{C}$. При цьому сума температур за оптимальних значеннях для росту і розвитку коренеплодів мала б коливатися в межах 1200-1500 ${ }^{\circ} \mathrm{C}$. Тобто температурні умови були несприятливими для формування якісних коренеплодів столового буряка, але вони в певній мірі нівелювалися краплинним зрошенням.

Товарність врожаю за першого строку сівби була на рівні 89-94 \%, за другого - 87-93 \%. Серед дослідних гібридів істотно низька (НIP05=2 \%) товарність коренеплодів відмічена у Боро $F_{1}: 87-89 \%$. Цей гібрид був також більш сприйнятливий до посушливих умов порівняно 3 іншими. Істотно вищий вихід товарних коренеплодів за першого строку сівби був у Бетті $F_{1}$ $94 \%$. За сівби у третю декаду травня він також формував велику кількість товарних коренеплодів - 93 \%. Слід відмітити гібрид Манзу $F_{1}$ : у 2020 р. він формував врожай з високою товарністю незалежно від строку сівби - $92 \%$.

Дисперсійним аналізом встановлено, що товарність врожаю на 61 \% залежала від особливостей гібрида (фактор В), строк сівби (фактор А) та сукупна дія фракторів $\mathrm{AB}$ впливали на цей 
показник відповідно на 3 та 2 \%. Інші фрактори вливали на товарність врожаю на $34 \%$.

Наразі до продукції буряка столового ставлять нові вимоги, які задовільнятимуть споживача, а саме: висока товарність і висока якість продукції. Сучасний споживач віддає перевагу коренеплодам невеликого розміру - діаметром 6-8 см, масою 250-350 г. Причому на першому місці не завжди стоїть урожайність. При порушенні технології вирощування отримують крупні коренеплоди діаметром понад 10-12 см і масою більше 500 г, які практично майже не можна реалізувати в супермаркеті $[15,16]$.

У наших дослідженнях всі товарні коренеплоди були стандартними, відрізнялися вирівненістю, їхній діаметр не перевищував 7,5-9,0 см, тому продукція відносилася до I товарного сорту. Менший діаметр був у коренеплодів Бетті $F_{1}$.

Маса коренеплодів буряка столового (табл. 2) відрізнялася залежно від строків сівби: за сівби у другій декаді квітня вона була більша, ніж за третьої декади травня на 3-4 \%. Коренеплоди найбільшої маси формував гібрид Манзу $F_{1}$ : 316,5 г - за першого строку сівби, 307,8 г - за другого строку. Найменша маса коренеплоду була у Бетті $F_{1}: 286,5$ г - за першого строку сівби та 282,5 г - за другого. Різниця за показником як між гібридами, так і за строками сівби була істотною $\left(\mathrm{HIP}_{05}=2,1\right.$ г).

Таблиця 2 Фізичні властивості коренеплодів буряка столового залежно від строку сівби, 2020 р.

\begin{tabular}{|c|c|c|}
\hline Строк сівби & Maca, г & Oб'єм, $\mathrm{CM}^{3}$ \\
\hline \multicolumn{3}{|c|}{ Боро $F_{1}$} \\
\hline $\begin{array}{c}\text { 1. } 13.04-\text { ко- } \\
\text { нтроль }\end{array}$ & 295,3 & 285,3 \\
\hline 2. 25.05 & 282,5 & 273,5 \\
\hline \multicolumn{3}{|c|}{ Манзу $F_{1}$} \\
\hline $\begin{array}{c}\text { 1. } 13.04-\text { ко- } \\
\text { нтроль }\end{array}$ & 316,5 & 305,5 \\
\hline 2. 25.05 & 307,8 & 296,7 \\
\hline \multicolumn{3}{|c|}{ Бетті $F_{1}$} \\
\hline $\begin{array}{c}\text { 1. } 13.04-\text { ко- } \\
\text { нтроль }\end{array}$ & 286,5 & 277,5 \\
\hline 2. 25.05 & 280,3 & 272,0 \\
\hline $\mathrm{HIP}_{05}$ & 2,1 & 1,9 \\
\hline
\end{tabular}

Об'єм коренеплоду як і його маса визначає товарні властивості екземплярів продукції. Дослідні гібриди мали коренеплоди округлої форми із об'ємом: за першого строку сівби - 277,5-285,3 $\mathrm{CM}^{3}$ та за другого строку - 272,0-296,7 см $^{3}$. Різниця була істотною як між гібридами, так і за строками сівби $\left(\mathrm{HIP}_{05}=1,9 \mathrm{~cm}^{3}\right)$.

Дисперсійним аналізом встановлено, що маса та об'єм коренеплоду буряка столового залежали від стоку сівби (фактор А) лише на $12 \%$, значний вплив на формування цих двох показників чинили особливості гібрида (фактор В) - 84-85 \%, сумісна дія фракторів АВ становила $1 \%$, решта впливу припадала на інші фрактори.

Висновки: сівба насіння буряка столового за оптимальної температури $20 \ldots 25^{\circ} \mathrm{C}$ забезпечує появу сходів на четверту добу. Тривалість вегетаційного періоду буряка столового подовжується за відхилення від оптимальної температури. Вищу врожайність коренеплодів буряк столовий фрормує за сівби у другу декаду квітня. Товарна врожайність і товарність продукції на 71 та $61 \%$ відповідно залежать від особливостей гібрида: найвища товарна врожайність коренеплодів була у гібрида Манзу $F_{1}: 70,8$ т/га. Товарність продукції цього гібрида залишалася на рівні $92 \%$ незалежно від строку сівби. Проте найвища товарність продукції була у гібрида Бетті $F_{1}$ : 93-94 \%, рівень товарної врожайності серед дослідних гібридів був найменшим - 55,9-59,7 т/га. Фізичні показники коренеплодів буряка столового на 66-85 \% залежать від особливостей гібрида і на 7-12 \% від строку сівби.

Перспективним $€$ вивчення інших фрізичних властивостей коренеплодів буряка столового та формування вмісту компонентів хімічного складу залежно від погодних умов вегетаційного періоду та елементів технології вирощування.

\section{Література:}

1. Галат Л. М. Особливості ринку свіжих овочів в Україні // Агросвіт, 2019. № 11. С. 35-44. doi:10.32702/2306-6792.2019.11.35

2. The official site Agropolit (2019), "In 2018 year Ukraine imported vegetables almost on 20 millions of dollars". URL: https://agro" polit.com/news, open document

3. The official site LLC "Green Team" (2019), "Cooling and storage of vegetables". URL: http://www.greenteam.ua/index.php/fermeram/khra nenie"ovoshchej, open document

4. Шевчук В.Д. Аналіз стану вирощування овочевої продукції в Україні // CHALLENGES IN SCIENCE OF NOWADAYS, InterConf, (13), 2020. P. 311-315. URL: https://ojs.ukrlogos.in.ua/ index.php/interconf/article/view/1823

5. Буряк звичайний - застосування в медицині / Лікарські рослини. URL: http://zillya.in.ua/ buryak-zvichajnij-zastosuvannya-v-medicini/

6. Корень В.В., Костюкєвич Т.К. Оцінка сучасного стану виробництва буряку столового в Україні // Матеріали Всеукраїнської науково-практичної конференції «Рубіновські читання», 2020 р. C. 20-21.

7. Стефанюк Г. Оптимальна технологія вирощування столових буряків // Пропозиція: Овочівництво, 2004. №3. С. 32-33.

8. Корниенко С. Особенности технологии выращивания свеклы столовой в Крыму // Агрономическая тетрадь, 2009. Вып. 4. С. 38. 
9. Слепцов Л. Столовая свекла: выбираем сорт. Овощеводство: Селекция и семеноводство. 2009. Вып. №3. С. 48.

10. Державний Реєстр сортів рослин, придатних для поширення в Україні на 2020 рік. Київ, 2020. С. 324-326.

11. ДСТУ 7033:2009. Буряк столовий свіжий. Технічні умови. [Чинний від 01.01.2010]. Київ, 2010. $10 \mathrm{c}$

12. Паламарчук І. І. Вплив строків сівби на формування врожаю буряку столового в Правобережному Лісостепу України // Вісник Уманського національного університету садівництва. Агрономія, 2020. № 1. С. 54-58.

13. Капустіна Л. Столові буряки від «Чайки» Плантатор, 2019. № 6. URL: https://agrotimes.ua/ article/stolovi-buryaky-vid-chajky/

14. Стефранюк С.В. Буряк столовий на зберігання // ^ОГО 10.36074/26.06.2020.v1.17

15. Енеді К.Л., Садовська Н.П. Урожайність буряка столового залежно від строків висіву // Young Scientist, 2016. № 2 (29).

16. Mashela P. W. Interrelations between commercial beetroot (Beta vulgaris) cultivars and Meloidogyne species // Acta Agriculturae Scandinavica, Section B - Soil \& Plant Science, 2017. Vol. 67. Issue 2. P. 164-168. doi: https://doi.org/10.1080/09064710.2016.1239757

\section{References:}

1. Galat, L. M. (2019) 'Osoblivosti rinku svizhih ovochiv v Ukrayini', Agrosvlt, (11), pp. 35-44. doi:10.32702/2306-6792.2019.11.35

2. In 2018 year Ukraine imported vegetables almost on 20 millions of dollars (2019) The official site Agropolit. Available at: https://agro" polit.com/news, open document (Accessed: 8 August 2020).

3. Cooling and storage of vegetables (2019) The official site LLC "Green Team". Available at: http://www.greenteam.ua/index.php/fermeram/khra nenie"ovoshchej, open document (Accessed: 8 August 2020).

4. Shevchuk, V. D. (2020) 'Analiz stanu viroschuvannya ovochevoyi produktsiyi v Ukrayini', CHALLENGES IN SCIENCE OF NOWADAYS,
InterConf, (13), pp. 311-315. Available at: https://ojs.ukrlogos.in.ua/index.php/interconf/article/ view/1823 (Accessed: 20 August 2020).

5. 'Buryak zvichayniy - zastosuvannya v meditsini', Likarski roslini. Available at: http://zillya.in.ua/buryak-zvichajnij-zastosuvannyav-medicini/ (Accessed: 20 August 2020).

6. Koren, V. V. and Kostyukevich, T. K. (2020) 'Otsinka suchasnogo stanu virobnitstva buryaku stolovogo v Ukrayini', Materiali Vseukrayinskoyi naukovo-praktichnoyi konferentsiyi «Rubinovski chitannya», pp. 20-21.

7. Stefanyuk, G. (2004) 'Optimalna tehnologiya viroschuvannya stolovih buryakiv', Propozitsiya: Ovochivnitstvo, (3), pp. 32-33.

8. Kornienko, S. (2009) 'Osobennosti tehnologii vyiraschivaniya sveklyi stolovoy v Kryimu', Agronomicheskaya tetrad, (4), p. 38.

9. Sleptsov, L. (2009) 'Stolovaya svekla: vyibiraem sort', Ovoschevodstvo: Selektsiya i semenovodstvo, (3), p. 48.

10. Derzhavniy Reestr sortiv roslin, pridatnih dlya poshirennya v Ukrayini na 2020 rik. Kiyiv, 2020, pp. 324-326.

11. DSTU 7033:2009. Buryak stoloviy svizhiy. Tehnichni umovi. [Chinniy vid 01.01.2010]. Kiyiv, 2010, $10 \mathrm{p}$

12. Palamarchuk, I. I. (2020) 'Vpliv strokiv sivbi na formuvannya vrozhayu buryaku stolovogo $v$ Pravoberezhnomu Lisostepu Ukrayini', Visnik Umanskogo natsionalnogo universitetu sadivnitstva. Agronomlya, (1), pp. 54-58.

13. Kapustina, L. (2019) 'Stolovi buryaki vid "Chayki»', Plantator, (6). Available at: https://agrotimes.ua/article/stolovi-buryaky-vidchajky/ (Accessed: 8 August 2020).

14. Stefanyuk, S. V. (2020) 'Buryak stoloviy na zberigannya', $\Lambda$ ОГО $\Sigma$, pp. 46-47. doi: 10.36074/26.06.2020.v1.17

15. Enedi, K. L. and Sadovska, N. P. (2016) 'Urozhaynist buryaka stolovogo zalezhno vid strokiv visivu', Young Scientist, (2(29)), p.12.

16. Mashela, P. W. (2017) 'Interrelations between commercial beetroot (Beta vulgaris) cultivars and Meloidogyne species', Acta Agriculturae Scandinavica, Section B - Soil \& Plant Science, (67(2)), pp. 164-168. doi: https://doi.org/10.1080/09064710.2016.1239757.

\section{Аннотация}

\section{Урожайность и физические свойства свеклы столовой при разных сроках посева}

\section{Л.М. Пузик, В.А. Бондаренко}

Представлены результаты опыта по изучению влияния разных сроков посева на урожайность свеклы столовой и их влияние на формирование физических свойств корнеплодов.

Исследование проводили с гібридами иностранной селекции Боро $F_{1}$, Манзу $F_{1}$ и Бетти $F_{1}$. Семена свеклы столовой высевали в два срока: вторая декада апреля и третья декада мая. Установлено, что срок посева влияет на скорость прорастания семян и появление всходов свеклы столовой: при высеве

Інженерія природокористування, 2020, №4(18), с. 47 - 52

Engineering of nature management, 2020, \#4(18), p. 47 - 52 
в третьей декаде мая всходы появлялись на 12 суток раньше, чем при высеве во второй половине апреля. Длительность вегетационного периода свеклы зависит от температуры почвы. Так как оптимальной температурой для роста и развития корнеплодов является $20 \ldots 25^{\circ} \mathrm{C}$, то выше или ниже этой температуры ростове процессы заметляються и тем самым удлиняется вегетационный период до наступления технической спелости.

Высокую урожайность корнеплодов свекла столовая формировала при высеве во второй декаде апреля. Товарная урожайность и товарность продукции на 71 и 61 \% соответственно зависели от особенностей гибрида. Высокий урівень товарной урожайности был у Манзу $F_{1}$ при посеве во второй декаде апреля составил 70,8 т/га, при посеве в третьей декаде мая товарная урожайность была 65,6 т/га. Товарность продукции у Манзу $F_{1}$ при первом и втором сроках сева сохранялась на уровне $92 \%$. В то время как у гибрида Бетті $F_{1}$ товарность была на уровне 93-94 \% при самой меньшей среди исследуемых гибридов урожайности: 55,9-59,7 т/га.

Такие физические показатели свеклы столовой как маса и объем корнеплодов зависели от особенностей гибрида соответственно на 85 и 84 \%. Влияние срока посева было от 7 до 12 \%. Существенно выше физические показатели корнеплодов были при высеве во второй декаде апреля. Корнеплоды существенно большие по массе и обьему формировал Манзу $F_{1}-307,8-316,5$ г и 296,7-305,5 м³ соответственно.

Ключевые слова: свекла столовая, гибрид, урожайность, товарность, корнеплод, масса, объем, срок посева.

\section{Annotation}

\section{Productivity and physical properties of beetroot at different sowing time}

\section{L.M. Pusik, V.A. Bondarenko}

The results of the experiment on the study of the influence of different sowing dates on the yield of beetroot and their influence on the formation of the physical properties of root crops are presented.

The study was carried out with foreign selection hybrids Boro $F_{1}$, Manzu $F_{1}$ and Betty $F_{1}$. Beetroot seeds were sown in two periods: the second decade of April and the third decade of May. It was found that the sowing time affects the rate of seed germination and the emergence of seedlings of beetroot: when sowing in the third decade of May, seedlings appeared 12 days earlier, than when sowing in the second half of April. The length of the beet growing season depends on the soil temperature. Since the optimal temperature for the growth and development of root-crops is $20 \ldots 25^{\circ} \mathrm{C}$, then above or below this temperature, the growth processes are observed and thus the growing season is lengthened until the onset of technical ripeness.

Beetroot formed a high yield of root-crops when sowing in the second decade of April. Marketable yield and marketability of products by 71 and $61 \%$, respectively, depended on the characteristics of the hybrid. A high level of marketable yield was at Manzu $F_{1}$, when sowing in the second decade of April was 70,8 t/ha, when sowing in the third decade of May, the marketable yield was $65,6 \mathrm{t} / \mathrm{ha}$. The marketability of products at Manzu $F_{1}$ during the first and second sowing periods remained at $92 \%$. While the Betty $F_{1}$ hybrid had a marketability of $93-94 \%$ with the lowest yield among the studied hybrids: 55,9-59,7 t/ha.

Such physical indicators of beetroot as mass and volume of root-crops depended on the characteristics of the hybrid by 85 and $84 \%$, respectively. The influence of the seeding time was from 7 to $12 \%$. The physical indicators of root-crops were significantly higher when sown in the second decade of April. Root-crops are significantly large in weight and volume formed by Manzu $F_{1}-307,8-316,5 \mathrm{~g}$ and 296,7-305,5 $\mathrm{m}^{3}$, respectively.

Keywords: beetroot, hybrid, yield, marketability, root-crop, weight, volume, sowing time.

\section{Бібліографічне посилання/ Bibliography citation: Harvard}

Pusik, L.M. and Bondarenko, V.A. (2020) 'Productivity and physical properties of beetroot at different sowing time', Engineering of nature management, (4(18), pp. 47 - 52.

Подано до редакції / Received: 22.10.2020 